\title{
Assessment of Drinking Water Purification Plant Efficiency in Al-Hassa, Eastern Region of Saudi Arabia
}

\author{
El-Sayed A. Badr 1,2,*(D) and Ahmed A. Al-Naeem ${ }^{1}$ \\ 1 Department of Environment and Natural Resources, College of Agricultural and Food Sciences, \\ King Faisal University, Al-Hofuf, P.O. Box 420, 31982 Al-Hassa, Saudi Arabia; anaeem@kfu.edu.sa \\ 2 Environmental Sciences Department, Faculty of Science, Damietta University, \\ New Damietta City 34517, Egypt \\ * Correspondence: sobadr@kfu.edu.sa or ebadr@du.edu.eg; Tel.: +966-545959274
}

Citation: Badr, E.-S.A.; Al-Naeem, A.A. Assessment of Drinking Water Purification Plant Efficiency in Al-Hassa, Eastern Region of Saudi Arabia. Sustainability 2021, 13, 6122. https://doi.org/10.3390/su13116122

Academic Editor: Chunjiang An

Received: 2 April 2021

Accepted: 26 May 2021

Published: 28 May 2021

Publisher's Note: MDPI stays neutral with regard to jurisdictional claims in published maps and institutional affiliations.

Copyright: (C) 2021 by the authors. Licensee MDPI, Basel, Switzerland. This article is an open access article distributed under the terms and conditions of the Creative Commons Attribution (CC BY) license (https:// creativecommons.org/licenses/by/ $4.0 /)$.
Abstract: The quality of drinking water is an extremely important factor in public health. The main sources of drinking water in the Kingdom of Saudi Arabia (KSA) are bottled water, purified groundwater, and desalinated seawater. This study aimed to assess drinking water quality and evaluate the performance of water purification plants in Al-Hassa and with the aid of the water quality index (WQI). A total of 150 water samples were collected from 30 water purification plants. The physiochemical characteristics of drinking water, including the $\mathrm{pH}$, TDS, EC, turbidity, free chlorine, total hardness, anions $\left(\mathrm{Cl}, \mathrm{HCO}_{3}, \mathrm{SO}_{4}, \mathrm{NO}_{3}\right.$, and $\left.\mathrm{F}\right)$, cations $(\mathrm{Na}, \mathrm{K}, \mathrm{Ca}$, and $\mathrm{Mg}$ ), iron, and manganese, were investigated. The results revealed that the purified water was of acceptable quality for drinking with respect to the measured physiochemical characteristics. The overall water purification efficiency for the reduction in total dissolved salts and related anions and cations was over $90 \%$. For instance, the average TDS values in groundwater were $1916 \pm 806 \mathrm{mg} / \mathrm{L}$, which decreased to $118 \pm 32.9 \mathrm{mg} / \mathrm{L}$ in purified water. The WQI results showed that all the collected purified water samples were considered to be of excellent quality (class I) for drinking. Meanwhile, $81.7 \%$ of the untreated groundwater samples were considered to be poor quality (class III), and $11.7 \%$ were considered to be very poor quality (class IV) due to their high contents of dissolved salts. The purification of the groundwater improved its quality from very poor/poor quality (classes III and IV) to excellent water quality (class I). A Piper diagram revealed that $80 \%$ of the investigated groundwater samples were of the sodium chloride-sulfate water type. Overall, we found that the groundwater in the investigated area is not suitable for drinking purposes unless further purification techniques are applied.

Keywords: drinking water; water quality index; water purification plants; groundwater

\section{Introduction}

The availability of water in sufficient quantity and quality is essential for the survival of all known forms of life [1,2]. The increase in the world's population growth and correlated urban, industrial, and agricultural development has resulted in the increased consumption of limited water resources [3]. Today, the competition for scarce water resources is intense in many places across the world $[1,4]$. Saudi Arabia, as an arid country, suffers from the problems of water scarcity and limited renewable water resources [5-7]. According to the UNESCO Water Scarcity Index, Saudi Arabia is subject to extreme water shortage conditions [4]. The main sources of water supply for domestic purposes in Saudi Arabia are groundwater and/or seawater desalination [5,8,9]. Although seawater desalination can help to overcome the water scarcity problems in Saudi Arabia, it consumes a lot of energy [4].

Drinking water should be of sufficient quantity and meet certain water quality criteria to assure its safe consumption by the population $[10,11]$. Groundwater purification for domestic purposes takes place using a variety of techniques, such as ion exchange, reverse 
osmosis, electron dialysis, activated carbon adsorption, and the addition of disinfectant with the use of chlorine, ozone, or UV light [1,12]. Reverse osmosis in combination with activated carbon treatment provides one of the most definitive means of water purification. Groundwater purification is essential to ensure that treated water meets the established drinking water guidelines/standards, such as those of the Saudi Arabian Standards Organization (SASO 2009) [13] and the World Health Organization (WHO 2011) [14]. The regular monitoring of the quality of purified water is necessary to evaluate the efficiency of reverse osmosis and other purification techniques [15].

Groundwater in Saudi Arabia is subject to overexploitation and enhanced anthropogenic inputs of pollutants, due to various human activities, such as urbanization, industrialization, and agricultural expansion $[5,16]$. For example, recent agricultural developments have resulted in the extensive use of pesticides and chemical fertilizers and the reuse of treated sewage $[9,17]$. Groundwater contamination might lead to marked changes in drinking water quality, including physiochemical and biological characteristics $[5,18,19]$. High levels of nitrates, fluorides, and total dissolved solids (TDS), including cations and anions, are the main environmental problems affecting groundwater quality $[7,11]$. High levels of salinity in groundwater in the Al-Hassa area might have resulted from excessive pumping and resulting groundwater depletion, soil weathering, agricultural drainage, and sea water intrusion, along with dry climate conditions $[6,8,20-22]$. The evaluation of groundwater quality for domestic purposes has been investigated in several studies $[3,5,7,10,23]$.

Several studies have been conducted to evaluate drinking water sources in Saudi Arabia to promote public health. Massoud et al. 2011 [18] established a decision support system (using GIS) to manage water quality in Al-Hassa. Badr and Al-Naeem 2016 [13] assessed spatial and temporal variations in the potable water quality of the water distribution network in the Al-Hassa area. Al-Omran et al. 2015 [5] evaluated the drinking water quality of the main water network and household tanks in Riyadh. Aly et al. 2015 [3] used water quality index to assess the groundwater quality for drinking and irrigation purposes in Hafar Albatin. Other similar studies on the assessment of drinking water supplies have been conducted in Riyadh [9] and Al-Gassim [8].

The water quality index (WQI) is a simple mathematical model used to facilitate water quality assessment $[3,24]$. The WQI is an effective management tool that can be used by policy makers and stakeholders to easily judge water quality for various purposes [7,25]. WQI can be used to present a simple and concise method for assessing both groundwater and surface water quality for drinking and irrigation purposes [26-28]. WQI calculations consider the majority of physiochemical characteristics of water parameters. In a WQI calculation, a single water quality value is obtained by integrating different water quality variables $[27,29]$.

The proper monitoring and assessment of groundwater used for drinking is necessary for the sustainable management of limited water resources. The main objectives of this study were the monitoring of untreated groundwater, the evaluation of water purification plants efficiency, and the assessment of treated drinking water quality with the aid of a water quality index in Al-Hassa in the eastern region of Saudi Arabia. The study area is characterized by arid climate conditions, along with a high level of dissolved salts in groundwater aquifers. Thus, we conducted a water quality assessment based on the investigation of related physiochemical characteristics, including $\mathrm{pH}, \mathrm{TDS}, \mathrm{EC}$, turbidity, free chlorine, total hardness, anions $\left(\mathrm{Cl}, \mathrm{HCO}_{3}, \mathrm{SO}_{4}, \mathrm{NO}_{3}, \mathrm{~F}\right)$, cations $(\mathrm{Na}, \mathrm{K}, \mathrm{Ca}, \mathrm{Mg})$, and trace metals $(\mathrm{Fe}, \mathrm{Mn})$. This study is very important in terms of assessing drinking water quality, which is closely related to public health. Moreover, there are no detailed studies of using water quality index and purification plant efficiency to assess drinking water quality in the eastern region. 


\section{Materials and Methods}

\subsection{Study Area}

Al-Hassa is the largest oasis in the Arabian Peninsula and is located in the Eastern Province of KSA [22]. It is characterized by a dry climate, with an average annual rainfall of $80 \mathrm{~mm}$, an evaporation averaging $2600 \mathrm{~mm}$ /year, and a summer temperature that can reach $46{ }^{\circ} \mathrm{C}[4,30]$. Al-Hassa is agricultural oasis covering an area of $80 \mathrm{~km}^{2}$ and consists of 5 cities, 22 main villages, and another 55 small villages (named Hejrah) [6,15]. The eastern province of Saudi Arabia has three types of aquifer: a Neogene shallow aquifer, a Dammam medium depth aquifer, and a UER (Umm Er Radhuma) deep aquifer [6,22,31]. All of them are subject to over-pumping with a resulting increased salt content with time. Geology of the study area is characterized by sandstone, limestone, halite, gypsum, and anhydrite $[6,22]$.

The main sources of drinking water in the Al-Hasa area are the municipality water supply (distribution networks), private groundwater purification plants, and bottled water. Since municipality water has a high level of dissolved salts and bottled water is expensive, purified water from private purification plants is widely consumed by the local community [15]. The water sources used in private water purification plants include groundwater wells, municipality water, and mixtures of both groundwater and municipality water.

There are approximately 45 private water purification plants in the Al-Hassa region; all of them use sand filtration, active carbon filtration, and reverse osmosis techniques for water purification, with the addition of chlorine (sodium hypochlorite) as a disinfectant. These plants require continuous monitoring to assess water quality and improve the reverse osmosis and other purification techniques used. The current study assessed the quality of the drinking water produced from private water purification plants (Figure 1), with a focus on the physiochemical characteristics of water. The measured water quality variables include the $\mathrm{pH}$, TDS, EC (electrical conductivity), turbidity, free chlorine, total hardness, cations (calcium, magnesium, sodium, and potassium), anions (chloride, bicarbonate, and sulfate), nitrate, fluoride, iron, and manganese.

\subsection{Sample Collection}

This study was conducted twice in the winter (December 2015) and the summer (May 2016) seasons to investigate whether there are seasonal variations in the quality of potable water supply. A total of 30 major private water purification plants, which are geographically distributed in the Al-Hassa region, were chosen to investigate their water quality. Those selected plants were classified as 11 water purification plants in Al-Hofuf (1-11), 7 plants in Al-Mubarraz (12-18), 5 plants (19-23) in northern villages, and 7 plants (24-30) in eastern villages (Figure 1). In each survey, a total of 60 water samples were collected from both untreated groundwater (before purification) and treated groundwater (after purification) from the selected water purification plants. An additional three water purification plants (numbered 3, 13, and 15, as shown in Figure 1) with various capacities were chosen for the regular monitoring of water quality and to evaluate the purification efficiency. They were used for a period of four months. Hence, an additional 30 water samples were collected from these 3 purification plants before and after purification on regular basis in the period January-April 2016 to assess the performance of the water purification plants over time. Thus, the total number of water samples in this study was 150 , covering the majority of water purification plants in the Al-Hassa region. 


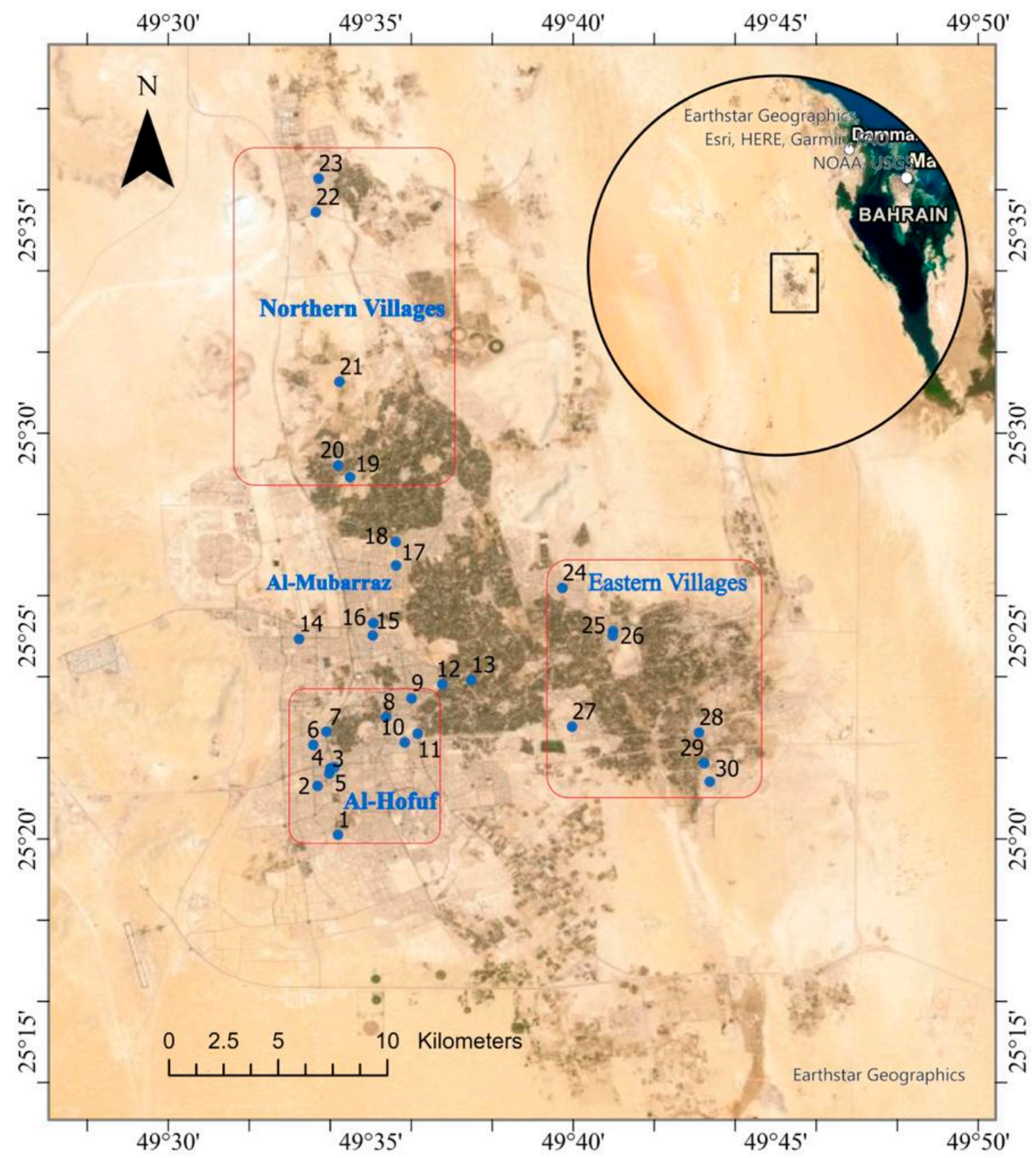

Figure 1. Geographic map of the Al-Hassa Oasis, KSA, showing the locations of the water purification plants investigated in this study.

In each water purification plant, water samples were collected from sources of groundwater and purified water outlets into pre-cleaned 1-L HDPE (high-density polyethylene) bottles and stored at $4{ }^{\circ} \mathrm{C}$ and in the dark until analysis. In situ water quality parameters include temperature, $\mathrm{pH}, \mathrm{TDS}, \mathrm{EC}$ and free chlorine; these were immediately measured in sample collection. All the glassware used was first acid-washed in $10 \% \mathrm{HCl}$ for $24 \mathrm{~h}$ then rinsed 3-5 times with distilled water and a water sample before use.

\subsection{Water Analysis}

Master water quality variables, including the $\mathrm{pH}$, TDS, EC, and free chlorine, were measured in situ. $\mathrm{pH}$ and temperature were measured in situ using a $\mathrm{pH}$ meter (model HI 9124, Hanna Instruments Ltd., Germany). The measurement of TDS and EC was performed using a Portable Conductivity/TDS meter (model 470-Digital, Jenway- UK) in units of $\mathrm{mg} / \mathrm{L}$ and micro-siemens per centimeter, respectively. Free chlorine was measured based on the DPD colorimetric method using a portable colorimeter (C301, OAKTON, Eutech, 
Singapore). Turbidity was measured using a turbidity meter (model HI 88703, Hanna Instruments Ltd., Germany) and expressed in NTU (Nephelometric Turbidity Units) [32].

The analysis of water samples was conducted in the laboratory using a well-established method in accordance with the American Standards for Water and Wastewater Examination Manual [32]. Nitrate, fluoride, and sulfate were measured in the collected water samples using a UV-Vis Spectrophotometer (UV-1650, Shimadzu), based on the UV-direct method, SPADNS method, and turbid-metric method, respectively [32-34]. Ions such as $\mathrm{Cl}, \mathrm{HCO}_{3}, \mathrm{Ca}$, and $\mathrm{Mg}$ (total hardness) were measured using well-established titrimetric methods [33]. Na and $\mathrm{K}$ were measured using the flame emission photometric method (Flame Photometer, Jenway, UK). Fe and Mn were measured using an atomic absorption spectrophotometer (AA6650F, Shimadzu, Japan) [32].

Analytical data quality was guaranteed through the implementation of laboratory quality assurance and quality control methods. These include the use of standard operating procedures, calibrations with standards, blank determination, and triplicate analysis of water samples. The coefficient of variation (CV) or precision of sample analysis was typically $<3-5 \%$. Moreover, the correctness of water chemical analysis was verified by calculating the ion balance error (up to $\pm 3 \%$ ) [5]. Statistical analysis was carried out using the SPSS software package (version 25.0). The basic statistics of the resulted data were analyzed, such as the average, minimum, maximum, median, standard deviation, and variance. The resultant data were also analyzed using one-way analysis of variance (ANOVA) to assess the significance variance between water samples collected from areas of Al-Hofuf, Al-Mubarraz, in the eastern villages and northern villages. The ANOVA critical values of $F$ (degree of freedom) were taken from the F-ratio table at the $p<0.01$ level of significance (the $99 \%$ confidence level), $n=60$. Moreover, investigations of the correlation matrix (Pearson's product moment) between pairs of water quality parameters were calculated to identify any statistically significant correlations $(p<0.01, \mathrm{n}=150)$ and thus aid in the interpretation of the data.

\subsection{Water Quality Index Computing}

The WQI calculations consider the majority of the physiochemical characteristics of water parameters, such as $\mathrm{pH}, \mathrm{TDS}, \mathrm{EC}$, turbidity, free chlorine, total hardness, anions $(\mathrm{Cl}$, $\left.\mathrm{HCO}_{3}, \mathrm{SO}_{4}, \mathrm{NO}_{3}, \mathrm{~F}\right)$, and cations ( $\mathrm{Na}, \mathrm{K}, \mathrm{Ca}, \mathrm{Mg}$ ), based on consulting a wide range of literature reviews $[7,24,27,28,35]$. The WQI was calculated for each collected water sample using the following empirical equations in order to evaluate the water quality $[25,26,36]$. First, each of the measured water parameters was assigned a weight $\left(\mathrm{w}_{\mathrm{i}}\right)$ of 1 to 5 according to its relative importance in the overall drinking water quality and based on the water quality standards presented in Table 1 . A maximum weight of 5 was assigned to parameters of relevant importance for drinking water such as TDS, while a weight of 2 was assigned to parameters with minor relevance such as bicarbonate [37,38]. Secondly, the relative weight (Wi) for each water quality parameter was then calculated using the following equation:

$$
\mathrm{Wi}=\frac{\mathrm{wi}}{\sum_{\mathrm{i}=1}^{\mathrm{n}} \mathrm{wi}}
$$

where Wi is the relative weight, wi is the weight of each parameter, and $\mathrm{n}$ is the number of parameters. The calculated relative weight (Wi) values of each parameter are presented in Table 1.

Thirdly, the quality rating scale (qi) for each parameter was computed by dividing the concentration of each water variable $(\mathrm{Ci})$ by its respective water quality standard for drinking $[13,14]$.

$$
\mathrm{qi}=\frac{\mathrm{Ci}}{\mathrm{Si}} * 100
$$

where qi is the quality rating scale, $\mathrm{Ci}$ is the concentration of each water variable, and $\mathrm{Si}$ is the WHO 2011 [16] standard for each water parameter. Lastly, the value of WQI was 
calculated by the sum of multiplying the quality rating scale (qi) of each parameter by its relative weight $(\mathrm{Wi})$.

$$
\mathrm{WQI}=\sum_{\mathrm{i}=1}^{\mathrm{n}} \mathrm{Wi} * \mathrm{qi}
$$

The calculated WQI values were classified into five groups, as shown in Table 2 . The WQI values ranged from $<50$ (excellent water quality) to value $>300$ (highly polluted water), which is unsuitable for the intended use.

Table 1. Relative weight (Wi) for each water quality parameter and the Saudi Arabian Standards Organization (SASO 2009) [13] and World Health Organization (WHO 2011) [14] standards for drinking water (maximum permissible limit).

\begin{tabular}{cccc}
\hline Parameters & Weight (wi) & Relative Weight (Wi) & $\begin{array}{c}\text { WHO (2011) and SASO } \\
\text { (2009) Standards }\end{array}$ \\
\hline $\mathrm{pH}$ & 3 & 0.061 & $6.5-8.5$ \\
TDS (mg/L) & 5 & 0.102 & 500 \\
Turbidity (NTU) & 3 & 0.061 & 5 \\
Free $\mathrm{Cl}_{2}(\mathrm{mg} / \mathrm{L})$ & 2 & 0.041 & $0.2-0.5$ \\
Total Hardness (mg/L) & 3 & 0.061 & 500 \\
Chloride (mg/L) & 4 & 0.082 & 250 \\
Bicarbonate $(\mathrm{mg} / \mathrm{L})$ & 2 & 0.041 & 125 \\
Sulphate $(\mathrm{mg} / \mathrm{L})$ & 3 & 0.061 & 250 \\
Nitrate $(\mathrm{mg} / \mathrm{L}$ as N) & 4 & 0.082 & 10 \\
Fluoride $(\mathrm{mg} / \mathrm{L})$ & 3 & 0.061 & 1.5 \\
Sodium $(\mathrm{mg} / \mathrm{L})$ & 4 & 0.082 & 200 \\
Potassium $(\mathrm{mg} / \mathrm{L})$ & 3 & 0.061 & 12 \\
Calcium $(\mathrm{mg} / \mathrm{L})$ & 3 & 0.061 & 50 \\
Magnesium $(\mathrm{mg} / \mathrm{L})$ & 3 & 0.061 & 300 \\
Iron $(\mu \mathrm{L} / \mathrm{L})$ & 2 & 0.041 & 100 \\
Manganese $(\mu \mathrm{g} / \mathrm{L})$ & 2 & 0.041 & \\
\hline
\end{tabular}

Table 2. Water quality classification based on WQI values [3].

\begin{tabular}{ccc}
\hline Water Class & Type of Water & WQI Value Range \\
\hline I & Excellent water & $<50$ \\
II & Good water & $50-100$ \\
III & Poor water & $100-200$ \\
IV & Very poor water & $200-300$ \\
V & Water unsuitable for drinking & $>300$ \\
\hline
\end{tabular}

\section{Results and Discussion}

\subsection{Groundwater Quality}

Descriptive statistics for the groundwater quality parameters are presented in Table 3, and Supplementary Materials. The water temperature varied between 19.5 and $33.5^{\circ} \mathrm{C}$, with an average value of $24.3 \pm 4.39^{\circ} \mathrm{C}$. It was noticed that average temperature values of the water samples collected in May $2016\left(27.7 \pm 3.35^{\circ} \mathrm{C}\right)$ were relatively high compared to temperature values of those collected in December $2015\left(21.0 \pm 2.17^{\circ} \mathrm{C}\right)$. The $\mathrm{pH}$ values of the collected water samples ranged between 6.77 and 7.69, with an average value of $7.15 \pm 0.17 . \mathrm{pH}$ is an important indicator of water quality and the extent of pollution. The results of $\mathrm{pH}$ values recorded in this study fall within the range of the international and Saudi standards (6.5-8.5). The turbidity values of the groundwater samples ranged between 0.10 and $0.75 \mathrm{NTU}$, with an average value of $0.29 \pm 0.14 \mathrm{NTU}$ (Table 3). The concentrations of free chlorine $\left(\mathrm{Cl}_{2}\right)$ ranged between 0.03 and $0.16 \mathrm{mg} / \mathrm{L}$, with an average value of $0.08 \pm 0.03 \mathrm{mg} / \mathrm{L}$. 
Table 3. Descriptive statistics of the measured parameters and WQI values in groundwater samples collected from Al-Hassa Oasis, KSA, including ANOVA $F$ ratio of statistically significant variance.

\begin{tabular}{|c|c|c|c|c|c|c|}
\hline \multirow{2}{*}{ Parameters } & \multicolumn{4}{|c|}{ Groundwater Quality, All Data $(n=60)$} & \multirow{2}{*}{$\begin{array}{c}\text { December } 2015(\mathrm{n}=30) \\
\text { Average } \pm \text { SD }\end{array}$} & \multirow{2}{*}{$\begin{array}{c}\text { May } 2016(\mathrm{n}=30) \\
\text { Average } \pm \text { SD }\end{array}$} \\
\hline & Average \pm SD & Min & $\operatorname{Max}$ & ANOVA $F$ & & \\
\hline Temperature & $24.3 \pm 4.39$ & 19.5 & 33.5 & 4.06 & $21.0 \pm 2.17$ & $27.7 \pm 3.35$ \\
\hline $\mathrm{pH}$ & $7.15 \pm 0.17$ & 6.77 & 7.69 & 0.91 & $7.22 \pm 0.19$ & $7.08 \pm 0.11$ \\
\hline TDS (mg/L) & $1916 \pm 806$ & 850 & 5513 & 6.63 & $1868 \pm 706$ & $1965 \pm 905$ \\
\hline $\mathrm{EC}(\mu \mathrm{S} / \mathrm{cm})$ & $3191 \pm 1341$ & 1416 & 9173 & 6.74 & $3110 \pm 1170$ & $3273 \pm 1508$ \\
\hline Turbidity & $0.288 \pm 0.14$ & 0.100 & 0.745 & 0.94 & $0.263 \pm 0.16$ & $0.312 \pm 0.11$ \\
\hline Free $\mathrm{Cl}_{2}(\mathrm{mg} / \mathrm{L})$ & $0.083 \pm 0.03$ & 0.030 & 0.160 & 0.45 & $0.078 \pm 0.03$ & $0.089 \pm 0.02$ \\
\hline $\mathrm{Cl}(\mathrm{mg} / \mathrm{L})$ & $675 \pm 370$ & 253 & 2357 & 6.55 & $644 \pm 317$ & $707 \pm 419$ \\
\hline $\mathrm{HCO}_{3}(\mathrm{mg} / \mathrm{L})$ & $191 \pm 20.0$ & 130 & 228 & 4.98 & $185 \pm 22.9$ & $198 \pm 14.6$ \\
\hline $\mathrm{SO}_{4}(\mathrm{mg} / \mathrm{L})$ & $276 \pm 70.4$ & 167 & 596 & 4.00 & $276 \pm 57.8$ & $276 \pm 82.2$ \\
\hline $\mathrm{NO}_{3}(\mathrm{mg} \mathrm{N} / \mathrm{L})$ & $6.30 \pm 2.27$ & 0.635 & 14.6 & 1.10 & $6.24 \pm 2.24$ & $6.35 \pm 2.33$ \\
\hline $\mathrm{F}(\mathrm{mg} / \mathrm{L})$ & $0.999 \pm 0.28$ & 0.538 & 1.94 & 1.06 & $1.03 \pm 0.26$ & $0.973 \pm 0.29$ \\
\hline $\mathrm{Na}(\mathrm{mg} / \mathrm{L})$ & $323 \pm 132$ & 117 & 988 & 4.30 & $291 \pm 101$ & $356 \pm 151$ \\
\hline $\mathrm{K}(\mathrm{mg} / \mathrm{L})$ & $50.0 \pm 30.7$ & 16.1 & 217 & 2.67 & $39.8 \pm 16.1$ & $60.1 \pm 38.0$ \\
\hline $\mathrm{Ca}(\mathrm{mg} / \mathrm{L})$ & $158 \pm 68.9$ & 82.5 & 459 & 10.33 & $172 \pm 74.9$ & $143 \pm 60.0$ \\
\hline $\mathrm{Mg}(\mathrm{mg} / \mathrm{L})$ & $52.7 \pm 24.9$ & 19.3 & 141 & 3.77 & $59.9 \pm 19.0$ & $45.5 \pm 28.2$ \\
\hline Hardness $(\mathrm{mg} / \mathrm{L})$ & $611 \pm 254$ & 344 & 1503 & 8.83 & $677 \pm 232$ & $545 \pm 261$ \\
\hline $\mathrm{Fe}(\mu \mathrm{g} / \mathrm{L})$ & $114 \pm 92.2$ & 26.2 & 311 & 2.78 & $82.3 \pm 68.0$ & $146 \pm 103$ \\
\hline $\operatorname{Mn}(\mu \mathrm{g} / \mathrm{L})$ & $35.9 \pm 18.9$ & 6.49 & 89.9 & 0.29 & $34.0 \pm 18.3$ & $37.8 \pm 19.6$ \\
\hline WQI & $155 \pm 59.2$ & 82.3 & 445 & 6.01 & $148 \pm 46.8$ & $161 \pm 69.7$ \\
\hline
\end{tabular}

Bold $F$ ratio is significant at $p$ "probability" $<0.01$ significance level (critical $F$ value $=4.16$ ).

The values of TDS ranged between 850 and $5513 \mathrm{mg} / \mathrm{L}$, with an average of $1916 \pm 806 \mathrm{mg} / \mathrm{L}$; meanwhile, the average concentrations of EC were $3191 \pm 1341 \mu \mathrm{S} / \mathrm{cm}$ and ranged between 1416 and $9173 \mu \mathrm{S} / \mathrm{cm}$. Higher TDS (and EC) values were observed in groundwater samples collected in May 2016 (range: 1162-5513 mg/L) relative to the water samples collected in December 2015 (range: 850-4024 mg/L). The temporal changes in water salinity might be due to the excessive pumping of groundwater for agriculture and domestic uses [22]. Exactly 1.7\%, $68.3 \%$, and $30 \%$ of the collected groundwater samples had TDS values of less than $1000 \mathrm{mg} / \mathrm{L}$, in the range of $1000-2000 \mathrm{mg} / \mathrm{L}$, and higher than $2000 \mathrm{mg} / \mathrm{L}$, respectively. These results indicated that the groundwater in the study area could not be used for drinking without further purification processes due to the high salt content, as all the TDS values exceeded the permissible limit of $500 \mathrm{mg} / \mathrm{L}$ according to the drinking water standards $[13,14]$. It has been observed that the elevated groundwater salinity in different areas of the country, such as the Al-Hassa Oasis, Hafar Albatin, the AlQassim region, and Al-Madinah City, resulted from the excessive pumping of groundwater, agricultural drainage, and soil weathering $[3,7,8,20]$.

High salinity levels (TDS > $1200 \mathrm{mg} / \mathrm{L}$ ) in groundwater may lead to excessive scale formation in boilers and household equipment, affecting public health [11]. It has been reported in a similar study that most groundwater wells in the central and eastern part of the KSA are relatively highly saline, which might be due to over pumping and arid conditions [11,39].

\subsubsection{Groundwater Anions}

The results for the numbers of anions $\left(\mathrm{Cl}, \mathrm{HCO}_{3}, \mathrm{SO}_{4}, \mathrm{NO}_{3}\right.$, and $\left.\mathrm{F}\right)$ measured in the collected groundwater samples are presented in Table 3. The chloride $(\mathrm{Cl})$ concentrations were in the range of $253-2357 \mathrm{mg} / \mathrm{L}$, with an average of $675 \pm 370 \mathrm{mg} / \mathrm{L}$. Lower chloride values were measured in the groundwater samples collected in December 2015 (average of $644 \pm 317 \mathrm{mg} / \mathrm{L}$ ), relative to those of water samples collected in May 2016 (average of $707 \pm 419 \mathrm{mg} / \mathrm{L}$ ) (Table 3). The concentration range of bicarbonates measured in the collected groundwater samples was $130-228 \mathrm{mg} / \mathrm{L}$, with an average concentration of $191 \pm 20 \mathrm{mg} / \mathrm{L}$. Almost all of the collected groundwater samples had chloride and 
bicarbonate concentrations greater than the permissible limits of $250 \mathrm{mg} / \mathrm{L}$ and $125 \mathrm{mg} / \mathrm{L}$, respectively [13,14].

The average concentrations of sulfates in the collected groundwater were $276 \pm 70.4 \mathrm{mg} / \mathrm{L}$, with a range of $167-596 \mathrm{mg} / \mathrm{L}$. Relatively higher ranges of sulfates were reported for water samples collected in May 2016 (186-596 mg/L) compared to water samples collected in December $2015(167-425 \mathrm{mg} / \mathrm{L})$. Sulfate is a major ionic constituent, with $58.3 \%$ of the collected water samples having concentrations greater than the recommended guidelines of $250 \mathrm{mg} / \mathrm{L}$ for drinking water $[13,14]$. In a similar study, the average concentration of sulfates in the groundwater collected from Khamis Mushait (KSA) was $524 \pm 125 \mathrm{mg} / \mathrm{L}$, with $60 \%$ of water samples above concentrations of $200 \mathrm{mg} / \mathrm{L}$ [21]. Anthropogenic activities and the dissolution of sulfate-bearing rocks, such as gypsum $\left(\mathrm{CaSO}_{4} \cdot 2 \mathrm{H}_{2} \mathrm{O}\right)$, are the main sources of sulfates in groundwater [1,21].

The nitrate and fluoride concentrations in the collected groundwater samples mainly averaged around $6.30 \pm 2.27 \mathrm{mg}-\mathrm{N} / \mathrm{L}$ and $0.99 \pm 0.28 \mathrm{mg} / \mathrm{L}$, with ranges of $0.635-14.6 \mathrm{mg}$ $\mathrm{N} / 1$ and $0.54-1.94 \mathrm{mg} / \mathrm{L}$, respectively. An examination of the seasonal variations revealed no significant changes between the nitrate and fluoride values of water samples collected in December 2015 and those water samples collected in May 2016. Moreover, 13.3\%, 83.3\%, and $3.3 \%$ of the collected groundwater samples had nitrate values of less than $5 \mathrm{mg} / \mathrm{L}$, in the range of $5-10 \mathrm{mg} / \mathrm{L}$, and higher than $10 \mathrm{mg} / \mathrm{L}$, respectively. On the other hand, the result indicated that $61.7 \%, 31.6 \%$, and $6.7 \%$ of the collected groundwater samples had fluoride values of less than $1 \mathrm{mg} / \mathrm{L}$, in the range of $1-1.5 \mathrm{mg} / \mathrm{L}$, and higher than $1.5 \mathrm{mg} / \mathrm{L}$, respectively. The reported relatively high nitrate concentrations in the current study might have resulted from extensive anthropogenic activities within the study area, including rapid population growth and related activities, such as urbanization, agricultural activities, and industrial developments [11,17].

\subsubsection{Groundwater Cations}

The results for the numbers of cations ( $\mathrm{Na}, \mathrm{K}, \mathrm{Ca}$, and $\mathrm{Mg}$ ) measured in the collected groundwater samples are presented in Table 3 . The concentration ranges of sodium and potassium were $117-988 \mathrm{mg} / \mathrm{L}$ and $16.1-217 \mathrm{mg} / \mathrm{L}$, with average values of $323 \pm 132 \mathrm{mg} / \mathrm{L}$ and $49.9 \pm 30.7 \mathrm{mg} / \mathrm{L}$, respectively. Higher $\mathrm{Na}$ and $\mathrm{K}$ values were observed in water samples collected in May 2016 relative to water samples collected in December 2015. A total of $95 \%$ of the sodium values and almost all the measured values for potassium were above the permissible limits for drinking water of $200 \mathrm{mg} / \mathrm{L}$ and $12 \mathrm{mg} / \mathrm{L}$, respectively [13,14].

The concentrations of calcium in the collected groundwater samples averaged around $158 \pm 68.9 \mathrm{mg} / \mathrm{L}$ and ranged from 82.5 to $459 \mathrm{mg} / \mathrm{L}$, whereas the measured values for magnesium ranged from 19.3 to $141 \mathrm{mg} / \mathrm{L}$, with an average of $52.7 \pm 24.9 \mathrm{mg} / \mathrm{L}$. Moreover, higher calcium and magnesium values were observed in groundwater samples collected in December 2015 (averages of $172 \pm 74.9 \mathrm{mg} / \mathrm{L}$ and $59.9 \pm 19 \mathrm{mg} / \mathrm{L}$ ), relative to groundwater samples collected in May 2016 (averages of $143 \pm 60 \mathrm{mg} / \mathrm{L}$ and $45.5 \pm 28.2 \mathrm{mg} / \mathrm{L}$, respectively). Exactly $93.3 \%$ and $46.7 \%$ of the collected groundwater samples had calcium and magnesium concentrations above the permissible limits of $100 \mathrm{mg} / \mathrm{L}$ and $50 \mathrm{mg} / \mathrm{L}$ in drinking water, respectively $[13,14]$.

The total hardness values were measured in the collected groundwater samples for $\mathrm{CaCO}_{3}$ and averaged around $611 \pm 254 \mathrm{mg} / \mathrm{L}$, with a range of 344-1503 mg/L. Higher average total hardness values of $677 \pm 232 \mathrm{mg} / \mathrm{L}$ were observed in groundwater samples collected in December 2015 relative to those in groundwater samples collected in May 2016 $(545 \pm 261 \mathrm{mg} / \mathrm{L})$. These findings revealed that the groundwater samples collected from Al-Hassa Oasis were very hard, as $58.3 \%$ of the measured samples had values greater than the recommended guidelines of $500 \mathrm{mg} / \mathrm{L}[13,14]$. Water hardness values of more than $500 \mathrm{mg} / \mathrm{L}$ can consume more soap detergent and produce scale in heating vessels $[1,8]$.

The average concentrations of iron and manganese measured in the collected groundwater samples were $114 \pm 92.2 \mathrm{mg} / \mathrm{L}$ and $35.9 \pm 18.9 \mathrm{mg} / \mathrm{L}$, respectively, with ranges of $26.2-311 \mathrm{mg} / \mathrm{L}$ for Fe and 6.49-89.9 mg/L for Mn. Higher average values of iron 
$(146 \pm 103 \mathrm{mg} / \mathrm{L})$ were observed for groundwater samples collected in May 2016 relative to those collected in December $2015(82.3 \pm 68 \mathrm{mg} / \mathrm{L})$. A few of the water samples tested $(6.7 \%)$ had iron concentrations greater than the maximum permissible limits of $300 \mathrm{mg} / \mathrm{L}$, whereas all the measured magnesium values were lower than the maximum permissible limit of $100 \mathrm{mg} / \mathrm{L}$, respectively [13,14]. In similar study, $26.7 \%$ of the groundwater samples collected from Khamis Mushait (KSA) exceeded the maximum permissible limits for iron [21]. The main sources of Fe and $\mathrm{Mn}$ in groundwater include dissolution from parent rocks in contact with aquifers and the corrosion of metallic pipes, and these elements can cause stains and a metallic taste [21,40,41].

\subsubsection{Overall Groundwater Quality}

Generally, the average concentrations of TDS, $\mathrm{EC}$, anions $\left(\mathrm{Cl}, \mathrm{HCO}_{3}\right.$, and $\left.\mathrm{SO}_{4}\right)$, and cations (Na and K) in groundwater samples collected in May 2016 were high in comparison with those collected in December 2015. The higher values of TDS and major ions in groundwater in summer might be related to the arid climate of the area, along with its higher evaporation rates, agricultural drainage, and increasing use of groundwater pumping in the summer and resultant seawater intrusion $[7,11,20]$. On the other hand, the average concentrations of calcium and magnesium and total hardness in groundwater samples collected in December 2015 were higher than those of water samples collected in May 2016, probably due to dissolution from limestone parent rocks in the low-rainfall season. Higher concentrations of TDS, anions, and cations were observed in groundwater samples collected from northern and eastern villages compared to those collected from the central towns of Al-Hofuf and Al-Mubarraz, as supported by the ANOVA F significance values (Table 3 ).

The majority of the collected groundwater samples had values of TDS, anions $(\mathrm{Cl}$, $\mathrm{HCO}_{3}, \mathrm{SO}_{4}, \mathrm{NO}_{3}$ ), and cations $(\mathrm{Na}, \mathrm{K}, \mathrm{Ca}, \mathrm{Mg}$ ) and total hardness concentrations greater than the permissible limit for drinking water $[13,14]$. These findings indicate that the groundwater in the study area should be subject to further purification processes before it can be safely used for drinking/domestic purposes, as reported also by similar studies $[15,41,42]$. Groundwater contamination due to enhanced anthropogenic inputs of pollutants might result in marked changes in water quality $[5,16]$. The Piper trilinear diagram was used to show the chemical characteristics of the groundwater samples (Figure 2) based on their ionic composition [43]. It is indicated that $80 \%$ of the water samples are sodium chloride-sulfate water types, while the remaining $20 \%$ of water samples are calcium sulfate-chloride water types. These water types demonstrated that the geology of the study area is characterized by halite, gypsum, and anhydrite [3,22]. Thus, the current study revealed that the following chemical abundance order of the measured ions is $\mathrm{Cl}>\mathrm{SO}_{4}$ $>\mathrm{HCO}_{3}>\mathrm{NO}_{3}>\mathrm{F}$ for anions and $\mathrm{Na}>\mathrm{Ca}>\mathrm{Mg}>\mathrm{K}$ for cations. This ionic order might indicate the lithogenic origin of these ions in groundwater [19]. 


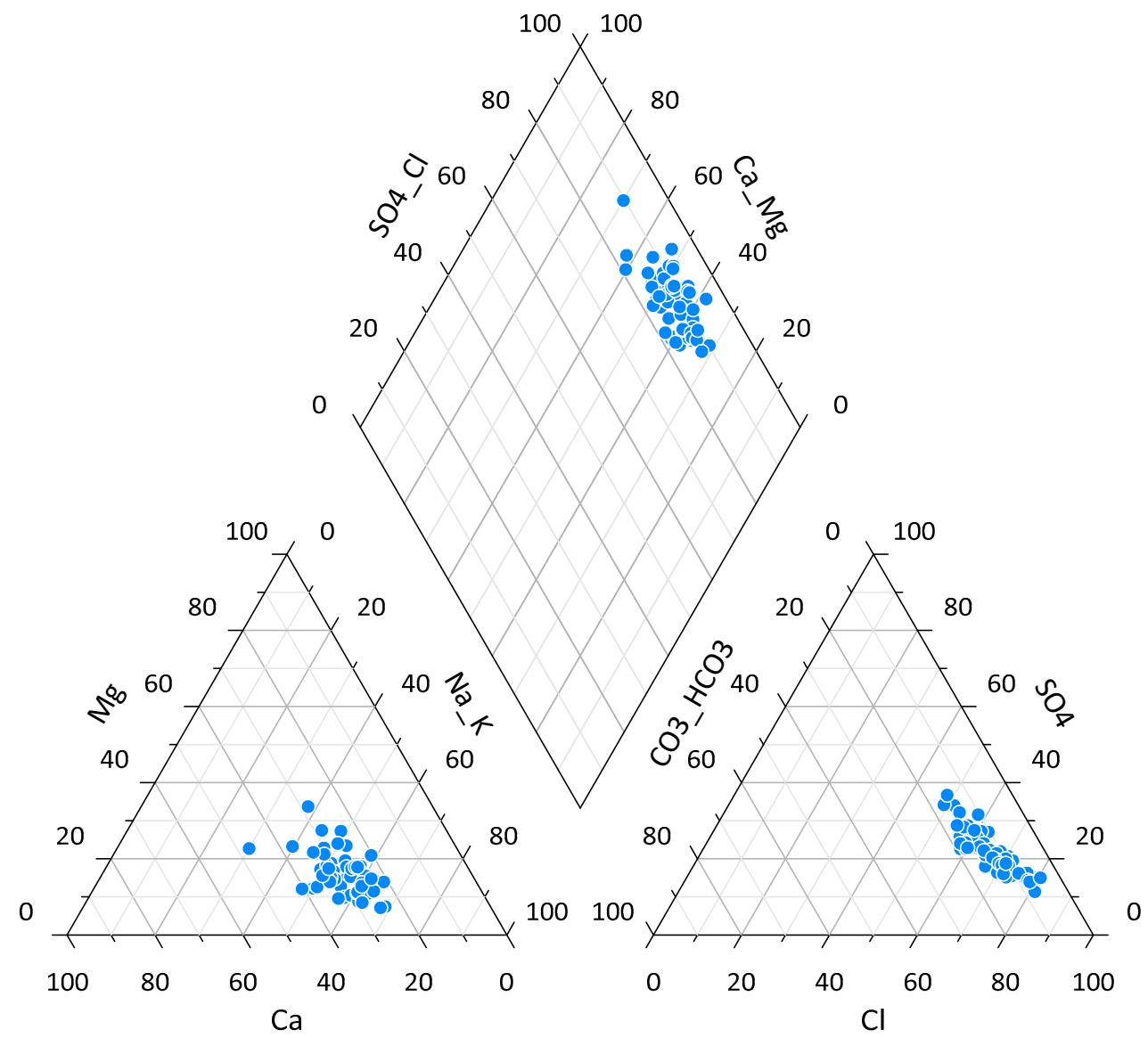

Figure 2. Piper trilinear diagram showing the major ionic composition of groundwater samples collected from Al-Hassa Oasis, KSA.

\subsection{Purified Drinking Water Quality}

Descriptive statistics for the purified drinking water quality characteristics are outlined in Table 4, and Supplementary Materials. The temperature values of the collected purified water ranged from 19.4 to $33.4{ }^{\circ} \mathrm{C}$, with an average value of $24.1 \pm 4.3^{\circ} \mathrm{C}$. It has been noticed that the average temperature values of the purified water samples collected in May $2016\left(27.5 \pm 3.3^{\circ} \mathrm{C}\right)$ were relatively high compared to the average temperature values of those collected in December $2015\left(20.8 \pm 1.7^{\circ} \mathrm{C}\right)$. The values of $\mathrm{pH}$ in the collected purified water samples ranged between 6.74 and 8.08, with an average value of $7.54 \pm 0.27$. The TDS values ranged between 50.6 and $265 \mathrm{mg} / \mathrm{L}$, with average value of $118 \pm 32.9 \mathrm{mg} / \mathrm{L}$. EC concentrations ranged between 82.8 and $442 \mu \mathrm{S} / \mathrm{cm}$, with an average value of $197 \pm 54.8 \mu \mathrm{S} / \mathrm{cm}$ of the 60 collected purified water samples, $26.7 \%, 58.3 \%, 13.3 \%$, and $1.7 \%$ had TDS values in the ranges of $50-100 \mathrm{mg} / \mathrm{L}, 100-150 \mathrm{mg} / \mathrm{L}, 150-200$, and $>200 \mathrm{mg} / \mathrm{L}$, respectively. The values of turbidity and free chlorine $\left(\mathrm{Cl}_{2}\right)$ in the purified water samples ranged from 0.10 to $0.78 \mathrm{NTU}$ and 0.04 to $0.84 \mathrm{mg} / \mathrm{L}$, with average values of $0.24 \pm 0.13 \mathrm{NTU}$ and $0.11 \pm 0.11 \mathrm{mg} / \mathrm{L}$, respectively. All the measured $\mathrm{pH}, \mathrm{TDS}$, turbidity, and free chlorine values in this study were within the permissible limit set by the WHO and the Saudi drinking water quality standards, as described in Table 1 [13,14]. 
Table 4. Descriptive statistics of the measured parameters and WQI values in the purified drinking water samples collected from Al-Hassa Oasis, KSA, including the ANOVA F ratio of statistically significant variance.

\begin{tabular}{|c|c|c|c|c|c|c|}
\hline \multirow{2}{*}{ Parameters } & \multicolumn{4}{|c|}{ Purified Water Quality, All Data $(n=60)$} & \multirow{2}{*}{$\begin{array}{c}\text { December } 2015(\mathrm{n}=30) \\
\text { Average } \pm \mathrm{SD}\end{array}$} & \multirow{2}{*}{$\begin{array}{c}\text { May } 2016(\mathrm{n}=30) \\
\text { Average } \pm \text { SD }\end{array}$} \\
\hline & Average \pm SD & Min & $\operatorname{Max}$ & ANOVA $F$ & & \\
\hline Temperature & $24.1 \pm 4.27$ & 19.4 & 33.4 & 3.13 & $20.8 \pm 1.75$ & $27.5 \pm 3.26$ \\
\hline $\mathrm{pH}$ & $7.54 \pm 0.27$ & 6.74 & 8.08 & 1.14 & $7.46 \pm 0.30$ & $7.61 \pm 0.21$ \\
\hline TDS (mg/L) & $118 \pm 32.9$ & 50.6 & 265 & 1.43 & $122 \pm 40.8$ & $115 \pm 22.7$ \\
\hline $\mathrm{EC}(\mu \mathrm{S} / \mathrm{cm})$ & $197 \pm 54.8$ & 82.8 & 442 & 1.41 & $203 \pm 68.1$ & $191 \pm 37.4$ \\
\hline Turbidity & $0.239 \pm 0.13$ & 0.100 & 0.783 & 0.31 & $0.247 \pm 0.16$ & $0.230 \pm 0.08$ \\
\hline Free $\mathrm{Cl}_{2}(\mathrm{mg} / \mathrm{L})$ & $0.106 \pm 0.11$ & 0.040 & 0.840 & 1.73 & $0.090 \pm 0.08$ & $0.122 \pm 0.14$ \\
\hline $\mathrm{Cl}(\mathrm{mg} / \mathrm{L})$ & $42.6 \pm 14.8$ & 17.4 & 130 & 2.30 & $44.3 \pm 18.8$ & $40.9 \pm 9.30$ \\
\hline $\mathrm{HCO}_{3}(\mathrm{mg} / \mathrm{L})$ & $17.9 \pm 6.61$ & 6.83 & 33.4 & 4.32 & $16.9 \pm 7.56$ & $18.9 \pm 5.46$ \\
\hline $\mathrm{SO}_{4}(\mathrm{mg} / \mathrm{L})$ & $11.8 \pm 6.70$ & 2.33 & 29.6 & 5.05 & $13.2 \pm 7.28$ & $10.5 \pm 5.88$ \\
\hline $\mathrm{NO}_{3}(\mathrm{mg} \mathrm{N} / \mathrm{L})$ & $0.881 \pm 0.43$ & 0.173 & 1.96 & 1.70 & $0.848 \pm 0.42$ & $0.914 \pm 0.45$ \\
\hline $\mathrm{F}(\mathrm{mg} / \mathrm{L})$ & $0.177 \pm 0.12$ & 0.036 & 0.579 & 1.85 & $0.197 \pm 0.08$ & $0.156 \pm 0.14$ \\
\hline $\mathrm{Na}(\mathrm{mg} / \mathrm{L})$ & $28.3 \pm 9.99$ & 8.33 & 83.6 & 2.81 & $28.1 \pm 12.5$ & $28.6 \pm 6.84$ \\
\hline $\mathrm{K}(\mathrm{mg} / \mathrm{L})$ & $3.72 \pm 1.08$ & 1.60 & 9.82 & 2.42 & $3.99 \pm 1.23$ & $3.45 \pm 0.84$ \\
\hline $\mathrm{Ca}(\mathrm{mg} / \mathrm{L})$ & $4.35 \pm 2.31$ & 1.78 & 15.1 & 0.84 & $5.41 \pm 2.54$ & $3.29 \pm 1.44$ \\
\hline $\mathrm{Mg}(\mathrm{mg} / \mathrm{L})$ & $3.46 \pm 1.41$ & 1.02 & 9.02 & 4.58 & $3.67 \pm 1.84$ & $3.25 \pm 0.75$ \\
\hline Hardness(mg/L) & $25.1 \pm 8.87$ & 13.6 & 54.8 & 3.16 & $28.6 \pm 10.9$ & $21.6 \pm 3.92$ \\
\hline $\mathrm{Fe}(\mu \mathrm{g} / 1)$ & $75.7 \pm 43.3$ & 20.5 & 187 & 1.19 & $66.2 \pm 39.0$ & $85.3 \pm 45.9$ \\
\hline $\operatorname{Mn}(\mu \mathrm{g} / \mathrm{l})$ & $27.7 \pm 16.1$ & 5.13 & 79.3 & 0.33 & $27.5 \pm 13.7$ & $27.9 \pm 18.5$ \\
\hline WQI & $18.9 \pm 2.78$ & 12.7 & 30.9 & 0.63 & $19.1 \pm 3.06$ & $18.8 \pm 2.51$ \\
\hline
\end{tabular}

Bold $F$ ratio is significant at the $p$ "probability" < 0.01 significance level (critical $F$ value $=4.16)$.

\subsubsection{Drinking Water Anions}

The results for the number of anions $\left(\mathrm{Cl}, \mathrm{HCO}_{3}, \mathrm{SO}_{4}, \mathrm{NO}_{3}\right.$, and $\left.\mathrm{F}\right)$ measured in the collected purified water samples are presented in Table 4 . The average concentrations of chloride $(\mathrm{Cl})$ were $42.6 \pm 14.8 \mathrm{mg} / \mathrm{L}$, with a range of $17.4-130 \mathrm{mg} / \mathrm{L}$. Lower chloride values were observed in water samples collected in May 2016 (average of $40.9 \pm 9.30 \mathrm{mg} / \mathrm{L}$ ) relative to water samples collected in December 2015 (average of $44.3 \pm 18.8 \mathrm{mg} / \mathrm{L}$ ). Bicarbonate concentrations were in the range of $6.83-33.4 \mathrm{mg} / \mathrm{L}$, with an average of $17.9 \pm 6.61 \mathrm{mg} / \mathrm{L}$. The average concentration of sulfates was $11.8 \pm 6.70 \mathrm{mg} / \mathrm{L}$, with a range of $2.33-29.6 \mathrm{mg} / \mathrm{L}$. It is reported that the sulfate concentration ranges from 48 to $360 \mathrm{mg} / \mathrm{L}$, with a mean value of $160 \mathrm{mg} / \mathrm{L}$, in drinking water of the Al-Gassim region [8]. All the measured purified water samples had chloride, bicarbonate, and sulfate concentrations lower than the permissible limits of $250 \mathrm{mg} / \mathrm{L}, 125 \mathrm{mg} / \mathrm{L}$, and $250 \mathrm{mg} / \mathrm{L}$, respectively, for drinking water $[13,14]$.

The average concentration of nitrate in the collected purified water samples was $0.88 \pm 0.43 \mathrm{mg}-\mathrm{N} / 1$, with a range of $0.17-1.96 \mathrm{mg}-\mathrm{N} / 1$, as indicated in Table 4 , whereas the concentrations of fluoride ranged between 0.04 and $0.58 \mathrm{mg} / \mathrm{L}$, with an average value of $0.18 \pm 0.12 \mathrm{mg} / \mathrm{L}$. An examination of the seasonal variations revealed no significant changes between the values of nitrate in the water samples collected in December 2015 and those in the water samples collected in May 2016. Generally, the nitrate and fluoride concentrations in the collected purified water samples were below the recommended limits of $10 \mathrm{mg} \mathrm{N} / \mathrm{L}$ and $1.5 \mathrm{mg} / \mathrm{L}$, respectively. The process of fluoridation needs to be considered for use in water purification plants, as the optimum recommended level of fluoride in drinking water is $0.8-1.5 \mathrm{mg} / \mathrm{L}[13,14]$.

\subsubsection{Drinking Water Cations}

The average concentrations of sodium and potassium in the collected purified water samples were $28.3 \pm 9.99 \mathrm{mg} / \mathrm{L}$ and $3.72 \pm 1.08 \mathrm{mg} / \mathrm{L}$, with ranges of $8.33-83.6 \mathrm{mg} / \mathrm{L}$ and 1.60-9.82 mg/L, respectively. Higher sodium and potassium values were observed in water samples collected in December 2015 (ranges: 12.4-83.6 mg/L and 2.87-9.82 mg/L) relative to those from water samples collected in May 2016 (ranges: $8.33-43.9 \mathrm{mg} / \mathrm{L}$ and 
$1.60-5.37 \mathrm{mg} / \mathrm{L}$ ). The concentration ranges of calcium and magnesium in the collected purified water samples were $1.78-15.2 \mathrm{mg} / \mathrm{L}$ and $1.02-9.02 \mathrm{mg} / \mathrm{L}$, respectively, with average values of $4.35 \pm 2.31 \mathrm{mg} / \mathrm{L}(\mathrm{Ca})$ and $3.46 \pm 1.41 \mathrm{mg} / \mathrm{L}(\mathrm{Mg})$. Moreover, an average higher calcium value of $5.41 \pm 2.54 \mathrm{mg} / \mathrm{L}$ was observed in purified water samples collected in December 2015, relative to those of water samples collected in May 2016, with an average of $3.29 \pm 1.44 \mathrm{mg} / \mathrm{L}$. Almost all the collected purified water samples had $\mathrm{Na}, \mathrm{K}, \mathrm{Ca}$, and $\mathrm{Mg}$ values within the permissible limits set for drinking water, as shown in Table 1 [13,14].

The total hardness concentrations in the collected purified water samples averaged $25.1 \pm 8.87 \mathrm{mg} / \mathrm{L}$, with a range of $13.6-54.8 \mathrm{mg} / \mathrm{L}$. Relatively higher total hardness values were observed in the purified water samples collected in December 2015 (average of $28.6 \pm 10.9 \mathrm{mg} / \mathrm{L}$ ) compared to those for water samples collected in May 2016 (average of $21.6 \pm 3.92 \mathrm{mg} / \mathrm{L}$ ). All the purified water samples had total hardness values less than the permissible limit of $500 \mathrm{mg} / \mathrm{L}$ in drinking water and would be considered as soft water $[13,14]$. The iron concentrations in the collected purified water samples were in the range of $20.5-187 \mathrm{mg} / \mathrm{L}$ and averaged a value of $75.7 \pm 43.4 \mathrm{mg} / \mathrm{L}$, whereas the concentration values of manganese averaged a value of $27.7 \pm 16.1 \mathrm{mg} / \mathrm{L}$, with a range of $5.13-79.3 \mathrm{mg} / \mathrm{L}$. All the collected purified water samples had iron and manganese values lower than the maximum permissible limits of $300 \mathrm{mg} / \mathrm{L}$ and $100 \mathrm{mg} / \mathrm{L}$, respectively [13,14]. Higher average values of iron $(85.3 \pm 45.9 \mathrm{mg} / \mathrm{L})$ were observed for purified water samples collected in May 2016 relative to those collected in December 2015 (66.2 $\pm 39 \mathrm{mg} / \mathrm{L})$.

\subsubsection{Overall Drinking Water Quality}

Generally, all the measured purified water samples had $\mathrm{pH}$, TDS, turbidity, anions $\left(\mathrm{Cl}, \mathrm{HCO}_{3}, \mathrm{SO}_{4}, \mathrm{NO}_{3}\right.$, and $\left.\mathrm{F}\right)$, cations $(\mathrm{Na}, \mathrm{K}, \mathrm{Ca}$, and $\mathrm{Mg})$, total hardness, and $\mathrm{Fe}$ and $\mathrm{Mn}$ concentrations within the permissible limits set for drinking water $[13,14]$. A similar study indicated that $95 \%$ of the purified drinking water in Al-Hassa meets the WHO criteria for drinking purposes [15]. The average concentrations of TDS, $\mathrm{EC}, \mathrm{Cl}, \mathrm{SO}_{4}, \mathrm{~F}$, and cations ( $\mathrm{Na}$, $\mathrm{K}, \mathrm{Ca}$ ) in the purified water samples collected in December 2015 were relatively high in comparison with those collected in May 2016. As shown in Table 4, ANOVA analysis ( $F$ ratios) indicated a significant variance $(p<0.01)$ of bicarbonate $(F=4.32, p=0.008)$, sulphate $(F=5.05, p=0.004)$, and magnesium $(F=4.58, p=0.006)$ measured in the water samples collected from the study area. The current study indicated the following ionic dominance order of $\mathrm{Cl}>\mathrm{HCO}_{3}>\mathrm{SO}_{4}>\mathrm{NO}_{3}>\mathrm{F}$ for anions and $\mathrm{Na}>\mathrm{Ca}>\mathrm{Mg}>\mathrm{K}$ for cations.

\subsection{Water Purification Plants' Efficiency}

The average removal efficiency for the total dissolved solids, anions, and cations using the studied water purification plants is illustrated in Figure 3. The TDS percent removal ranged from 79.8 to $98.1 \%$, with an average of $93 \pm 3.23 \%$. Meanwhile, the average concentrations of TDS decreased from $1916 \pm 806 \mathrm{mg} / \mathrm{L}$ in groundwater to $118 \pm 32.9 \mathrm{mg} / \mathrm{L}$ in purified water. Similarly, the average percentage removal of chloride, bicarbonate, and sulfate was $92.5 \pm 3.84 \%, 90.5 \pm 3.63 \%$, and $95.4 \pm 2.71 \%$, respectively. Meanwhile, the nitrate and fluoride percent removal averaged $85.6 \pm 5.76 \%$ and $82.4 \pm 10.7 \%$, respectively. As shown in Figure 3, the average percentage removal of cations $(\mathrm{Na}, \mathrm{K}, \mathrm{Ca}, \mathrm{Mg}$ ) was over $90 \%$. The total hardness percentage removal ranged from 89.3 to $98.6 \%$, as average concentrations reduced from $611 \pm 254$ to $25.1 \pm 8.87 \mathrm{mg} / \mathrm{L}\left(\mathrm{CaCO}_{3}\right)$ through a purification process. On the other hand, this result indicated the lower percentage removal of $\mathrm{Mn}$, averaging values of $23 \pm 18.1 \%$, Hence, further study is recommended in order to investigate the efficiency of water purification plants in removing trace metals $(\mathrm{Fe}, \mathrm{Mn}, \mathrm{Cu}$, and $\mathrm{Zn}$ ) from water. Overall, water purification techniques are essential to decrease the concentrations of dissolved solids, anions, and cations, and make groundwater suitable for safe human consumption $[1,41,42]$. 


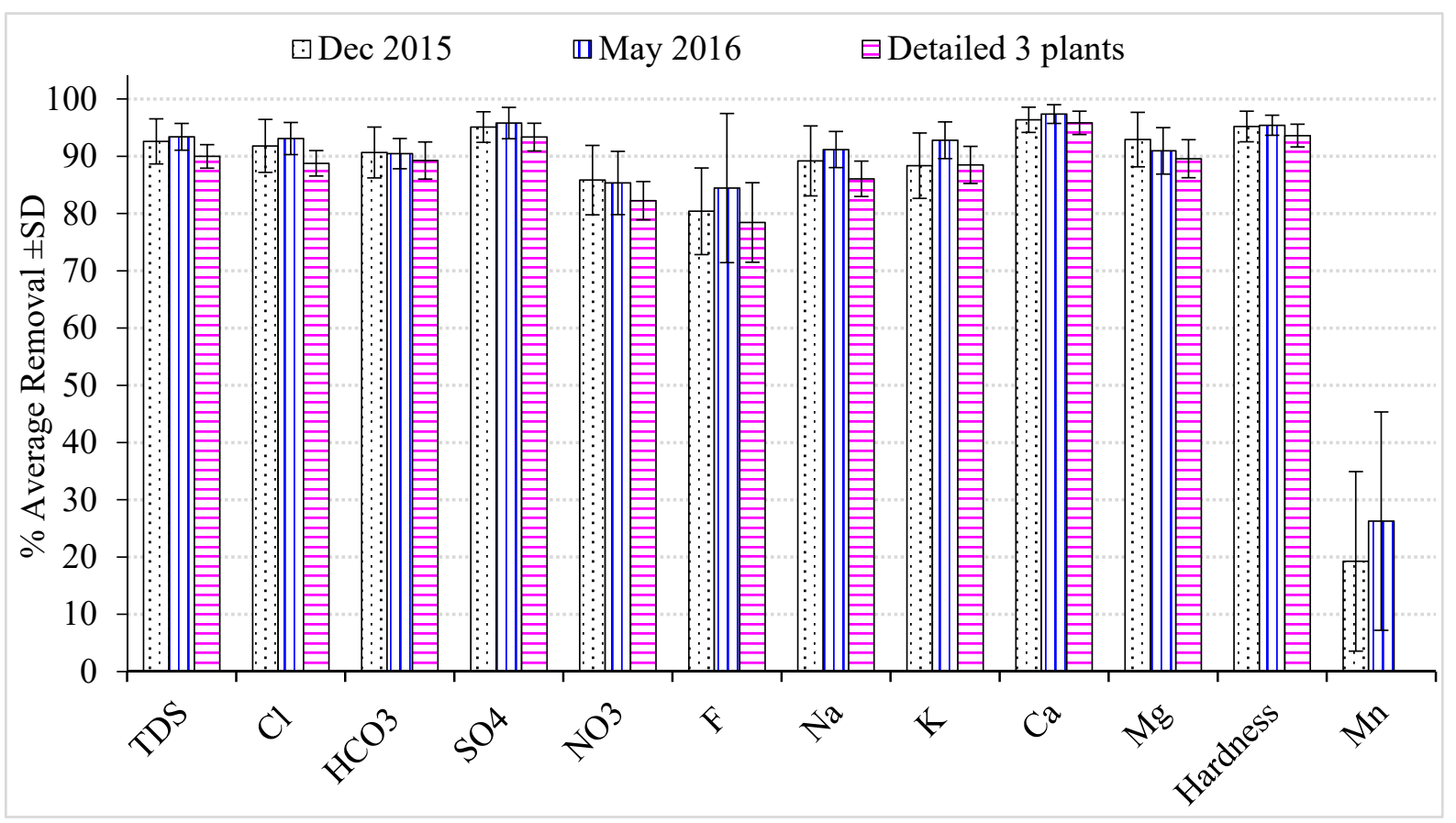

Figure 3. Purification efficiency ( $\%$ average removal \pm SD) of the 30 studied private water purification plants in Al-Hassa Oasis, KSA.

The results indicate that there was no significant difference between the average efficiency of removal in December 2015 and that in May 2016. Moreover, the detailed investigation of the three water purification plants over the period December 2015-May 2016 indicated that there were no significant variations in purification efficiency over time. For instance, the average TDS percentage removal ranged from 87 to $95 \%$, with a coefficient of variation of 2.3\% throughout the studied period of December 2015-May 2016. Therefore, results of the current study indicated that the investigated water purification plants were working efficiently, with an average rate of over $90 \%$. The studied water purification plants applied reverse osmosis and filtration processes, followed by the addition of chlorine as a disinfectant, removing total dissolved solids, anions $\left(\mathrm{Cl}, \mathrm{HCO}_{3}\right.$, and $\left.\mathrm{SO}_{4}\right)$, cations $(\mathrm{Na}$, $\mathrm{K}, \mathrm{Ca}$, and $\mathrm{Mg}$ ), and total hardness. Moreover, the results indicate that the purified water quality characteristics were consistent with the permissible limits set for drinking water. The availability of drinking water in sufficient quantity and quality is important to sustain public health and prevent the spread of waterborne diseases $[3,26,28]$.

\subsection{Water Quality Index}

The average value of the water quality index for all the collected groundwater samples is $155 \pm 59.2$, which is equivalent to poor or very poor water quality (Table 3 ). Higher WQI values were observed in groundwater samples collected in May 2016 (range: 101-445) relative to those for water samples collected in December 2015 (range: 82.3 -302) (Figure 4). The observed high WQI values are correlated with high values of TDS, EC, anions $(\mathrm{Cl}$, $\mathrm{HCO}_{3}$, and $\mathrm{SO}_{4}$ ), and cations ( $\mathrm{Na}$ and $\mathrm{K}$ ) measured in the groundwater samples collected in May 2016. The study area is characterized by dried conditions, along with increasing rates of groundwater pumping in summer for agricultural and domestic uses, resulting in a high salt content in groundwater $[6,11,22]$. Exactly $81.7 \%, 11.7 \%$, and $3.33 \%$ of the collected groundwater samples had WQI values that classified it as poor water (100-200), very poor water (200-300), and water unsuitable for drinking (>300), respectively. It has been observed that $47 \%$ of the untreated groundwater in Hafar Albatin could be considered unsuitable (class V), whereas $39 \%$ and $14 \%$ could be considered very poor and poor water 
for drinking purposes [3]. Moreover, $87 \%$ of the groundwater samples collected from Al-Madinah City were considered unsuitable (class V) for drinking purposes [7].

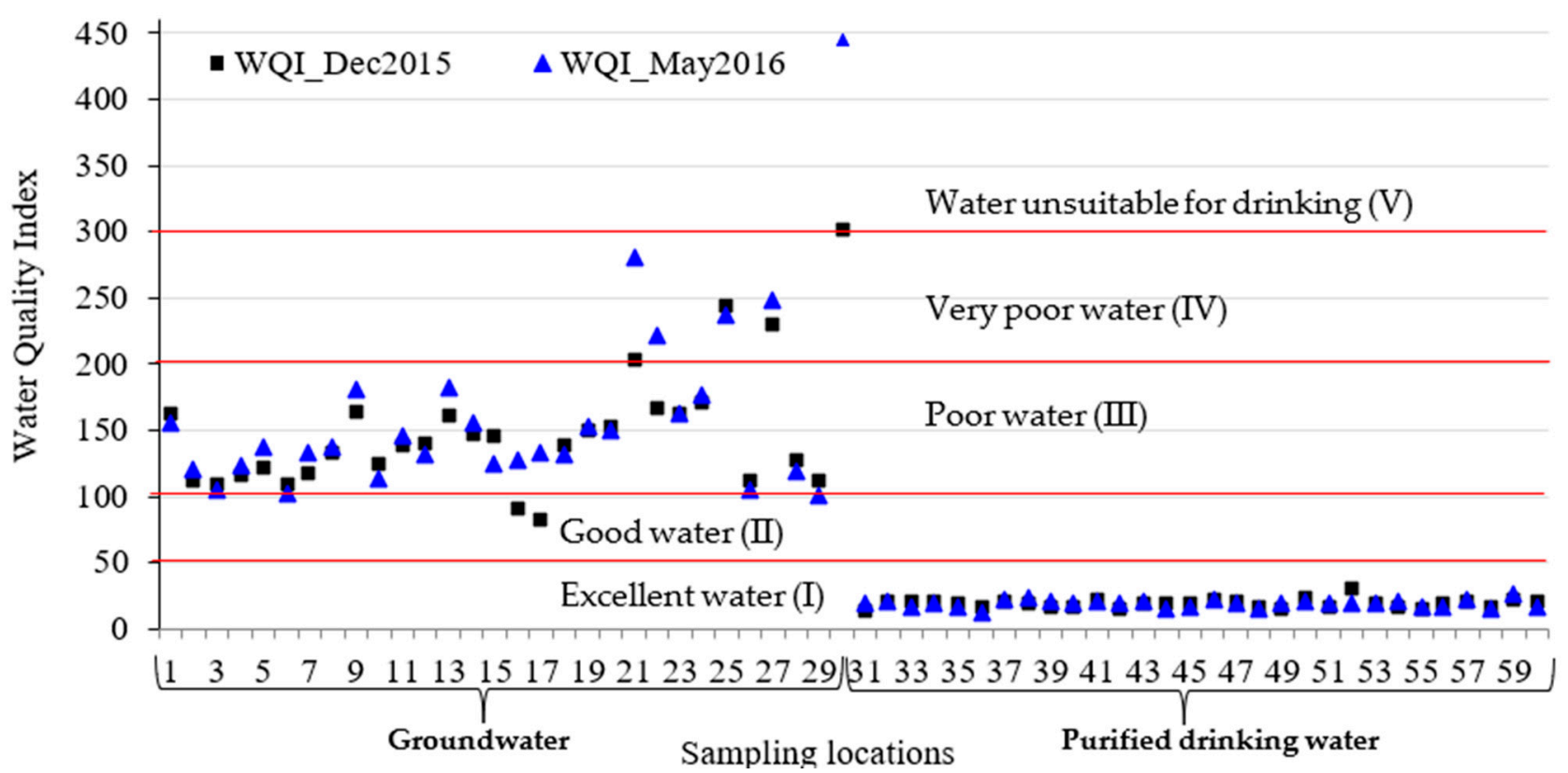

Figure 4. Values of WQI for the collected groundwater and purified drinking water from Al-Hassa Oasis, KSA.

On the other hand, $100 \%$ of the collected purified water samples could be classified as having excellent water quality for drinking (class I), as the WQI values ranged from 12.7 to 30.9 , with an average of $18.9 \pm 2.78$ (Table 4 and Figure 4 ). In similar studies, $88 \%$ of the drinking water of the Riyadh main zone was considered excellent for drinking, whereas $64 \%$ of the treated groundwater in Hafar Albatin was considered to be of good quality [3,5]. Moreover, $74 \%$ of the drinking water in primary schools of Pakistan was considered of excellent and good quality for drinking [28]. The results of the current study indicated that purification plants improved the groundwater quality from water class III-V to class $\mathrm{I}$, which is excellent for drinking purposes. Hence, the groundwater of the current study area should be subject to purification processes before use. Thus, WQI can be used as an effective management tool to facilitate drinking water quality assessment and support decision-making [26,27].

Since the competition for scarce water resources is intense in many countries, some water management strategies need to be employed to protect drinking water resources from pollution and sustain public health: first, by providing adequate potable water distribution networks covering both urban and rural areas of the community; second, by preventing drinking water resources from pollution through conducting environmental impact assessments (EIAs) for all anthropogenic projects; third, by establishing a periodic water quality monitoring and assessment program to ensure good drinking water quality; fourth, by investigating the efficiency of water purification plants through assessing various types of ion exchange materials and the reverse osmosis and filtration used in removing ions from water.

\subsection{Correlation between Water Quality Variables}

Pearson's correlation analysis was applied to analyze the relationships between different water quality parameters (Table 5). There were significant positive correlations between TDS and the following ions: chloride, bicarbonate, sulfates, nitrate, sodium, potassium, calcium, and magnesium, with correlation coefficients of $r=0.84-0.99(p<0.01)$. These strong correlations reflect the significant contributions of these ions to the acquisition of water mineralization. Moreover, all the following water quality parameters (TDS, $\mathrm{Cl}, \mathrm{HCO}_{3}$, 
$\mathrm{SO}_{4}, \mathrm{NO}_{3}, \mathrm{Na}, \mathrm{K}, \mathrm{Ca}$, and $\mathrm{Mg}$ ) were strongly correlated with each other $(\mathrm{r}=0.74-0.99$, $p<0.01)$. The significant positive correlations between $\mathrm{Mg}$ and $\mathrm{Cl}(\mathrm{r}=0.89)$ indicated that water hardness is permanent in nature [3].

Table 5. Correlation coefficient matrix of water quality parameters and WQI for water samples collected from Al-Hassa Oasis, KSA.

\begin{tabular}{|c|c|c|c|c|c|c|c|c|c|c|c|c|c|c|c|}
\hline & $\mathrm{pH}$ & TDS & TUR & $\mathrm{Cl}_{2}$ & $\mathrm{Cl}$ & $\mathrm{HCO}_{3}$ & $\mathrm{SO}_{4}$ & $\mathrm{NO}_{3}$ & $\bar{F}$ & $\mathrm{Na}$ & $\overline{\mathbf{K}}$ & $\mathrm{Ca}$ & $\overline{\mathrm{Mg}}$ & $\mathbf{F e}$ & Mn \\
\hline $\mathrm{pH}$ & 1.00 & & & & & & & & & & & & & & \\
\hline TDS & -0.33 & 1.00 & & & & & & & & & & & & & \\
\hline TUR & 0.14 & 0.18 & 1.00 & & & & & & & & & & & & \\
\hline $\mathrm{Cl}_{2}$ & 0.04 & -0.12 & -0.10 & 1.00 & & & & & & & & & & & \\
\hline $\mathrm{Cl}$ & -0.28 & 0.99 & 0.17 & -0.11 & 1.00 & & & & & & & & & & \\
\hline $\mathrm{HCO}_{3}$ & -0.41 & 0.89 & 0.19 & -0.15 & 0.82 & 1.00 & & & & & & & & & \\
\hline $\mathrm{SO}_{4}$ & -0.45 & 0.87 & 0.09 & -0.15 & 0.79 & 0.92 & 1.00 & & & & & & & & \\
\hline $\mathrm{NO}_{3}$ & -0.33 & 0.84 & 0.11 & -0.12 & 0.80 & 0.83 & 0.82 & 1.00 & & & & & & & \\
\hline F & -0.46 & 0.70 & 0.17 & -0.14 & 0.60 & 0.85 & 0.85 & 0.54 & 1.00 & & & & & & \\
\hline $\mathrm{Na}$ & -0.32 & 0.99 & 0.19 & -0.12 & 0.98 & 0.88 & 0.85 & 0.84 & 0.68 & 1.00 & & & & & \\
\hline $\mathbf{K}$ & -0.29 & 0.94 & 0.13 & -0.10 & 0.94 & 0.78 & 0.81 & 0.80 & 0.56 & 0.95 & 1.00 & & & & \\
\hline $\mathrm{Ca}$ & -0.36 & 0.96 & 0.14 & -0.13 & 0.93 & 0.89 & 0.90 & 0.82 & 0.74 & 0.92 & 0.85 & 1.00 & & & \\
\hline Mg & -0.34 & 0.92 & 0.11 & -0.14 & 0.89 & 0.84 & 0.87 & 0.77 & 0.75 & 0.88 & 0.83 & 0.91 & 1.00 & & \\
\hline $\mathrm{Fe}$ & -0.26 & 0.19 & 0.08 & 0.07 & 0.18 & 0.28 & 0.23 & 0.26 & 0.19 & 0.23 & 0.17 & 0.20 & 0.08 & 1.00 & \\
\hline Mn & -0.14 & 0.26 & 0.05 & -0.05 & 0.25 & 0.24 & 0.23 & 0.27 & 0.15 & 0.26 & 0.30 & 0.24 & 0.19 & 0.12 & 1.00 \\
\hline
\end{tabular}

Bold correlations are significant at the $p$ "probability" $<0.01$ significance level, $(\mathrm{N}=150)$.

The strong correlations among these measured variables suggest that they were influenced by the same environmental factors [11]. There was a weak but significant positive correlation ( $\mathrm{r}=0.26-0.28, p<0.01)$ between iron, bicarbonate, and nitrate. Additionally, there was a weak, but significant, negative correlation $(p<0.01)$ between $\mathrm{pH}$ and all the measured water quality parameters (except turbidity, chlorine, Mn). No significant correlation was observed between chlorine and other water quality parameters, such as chlorine, which is added at the end of purification processes as a disinfectant.

\section{Conclusions}

Water is essential for the survival of all forms of life, and it represents up to $70 \%$ of living beings' body weights. Many arid countries are suffering from water scarcity and limited freshwater resources. Providing a good drinking water quality in a sufficient quantity, along with assessing water purification plants, is essential to sustain human beings and protect the health of the whole world's population. This study focused on the assessment of drinking water quality in the Al-Hassa region of KSA, an arid country, through the physiochemical analysis of water parameters, compared with the drinking water standards of Saudi Arabia and the World Health Organization, and with the aid of the water quality index. The study also evaluates the performance of water purification plants in removing total dissolved salts, anions, and cations. WQI is considered a simple management tool with which to evaluate the overall water quality and has been widely used to judge its suitability for various purposes.

The obtained results indicated that the concentrations of the total dissolved solids, turbidity, soluble anions and cations, nitrate, fluoride, total hardness, iron, and manganese in most purified water samples collected from Al-Hassa were within the permissible limits set by the SASO and WHO drinking water standards. On the other hand, the majority of the collected groundwater samples exceeded the allowable limits set for drinking water quality. Higher values of TDS, anions, and cations were observed in groundwater collected in May 2016 and from villages (northern and eastern) than in those collected in December 2015 and from central towns (Al-Hofuf and Al-Mubarraz). Therefore, the groundwater in the study area should be subject to further purification processes before it can be used for drinking purposes. The Piper diagram revealed two different types of groundwater: the sodium chloride-sulfate water type ( $80 \%$ of samples) and the calcium sulfate-chloride water 
type. Overall, this research provides an overview of drinking water quality assessment and the evaluation of the water purification efficiency in the Al-Hassa region, which can be applicable in other similar places.

Supplementary Materials: The following are available online at https:/ / www.mdpi.com/article/10 $.3390 /$ su13116122/s1.

Author Contributions: Conceptualization, E.-S.A.B. and A.A.A.-N.; methodology E.-S.A.B.; software, E.-S.A.B.; validation, E.-S.A.B. and A.A.A.-N.; formal analysis, E.-S.A.B. and A.A.A.-N.; investigation, E.-S.A.B. and A.A.A.-N.; resources, E.-S.A.B. and A.A.A.-N.; data curation, E.-S.A.B. and A.A.A.-N.; writing-original draft preparation, E.-S.A.B.; writing-review and editing, E.-S.A.B. and A.A.A.N.; visualization, E.-S.A.B. and A.A.A.-N.; supervision, E.-S.A.B.; project administration, E.-S.A.B.; funding acquisition, E.-S.A.B. and A.A.A.-N. All authors have read and agreed to the published version of the manuscript.

Funding: This research was funded by the Deanship of Scientific Research, KFU, grant number 15008.

Data Availability Statement: Not Applicable.

Acknowledgments: The authors would like to acknowledge the help of the private water purification plants in Al-Hassa in providing the water samples used in this study. The comments of the anonymous reviewers are gratefully acknowledged.

Conflicts of Interest: The authors declare no conflict of interest.

\section{References}

1. Rojas, L.V.; Santos, J.A.; Corcho-Alvarado, J.A.; Amaral, R.S.; Rollin, S.; Milan, M.O.; Fernandez, Z.H.; Francis, K.; Cavalcanti, M.; Santos, J.M.N. Quality and management status of the drinking water supplies in a semiarid region of Northeastern Brazil. J. Environ. Sci. Health Part A Toxic/Hazard. Subst. Environ. Eng. 2020, 55, 1247-1256. [CrossRef] [PubMed]

2. Badr, E.A.; El-Sonbati, M.A.; Nassef, H.M. Water Quality Assessment in the Nile River, Damietta Branch, Egypt. Int. J. Environ. Sci. 2013, 8, 43-53. [CrossRef]

3. Aly, A.A.; Al Omran, A.M.; Alharby, M.M. The water quality index and hydrochemical characterization of groundwater resources in Hafar Albatin, Saudi Arabia. Arab. J. Geosci. 2015, 8, 4177-4190. [CrossRef]

4. Ghanim, A. Water-Resources-Crisis-in-Saudi-Arabia-Challenges-and-Possible-Management-Options-An-Analytic-Review. Int . J. Environ. Ecol. Eng. 2019, 13, 51-56.

5. Al Omran, A.; Al Barakah, F.; Altuquq, A.; Aly, A.; Nadeem, M. Drinking water quality assessment and water quality index of Riyadh, Saudi Arabia. Water Qual. Res. J. Can. 2015, 50, 287-296. [CrossRef]

6. Al-Naeem, A.A.; Al-Barrak, K.M. Assessment and evaluation of hydro-chemical and elemental analysis for Ain Al-Khadoud, Al-Hassa Oasis, Eastern Province, Saudi Arabia. J. Soil Sci. Agric. Eng. Mansoura Univ. 2010, 1, 815-826.

7. Alghamdi, A.G.; Aly, A.A.; Aldhumri, S.A.; Al Barakaha, F.N. Hydrochemical and Quality Assessment of Groundwater Resources in Al-Madinah City, Western Saudi Arabia. Sustainability 2020, 12, 3106. [CrossRef]

8. Al-Redhaiman, K.N.; Abdel Magid, H.M. The applicability of the local and international water quality guidelines to Al-Gassim region of central Saudi Arabia. Water Air Soil Pollut. 2002, 137, 235-246. [CrossRef]

9. Alabdula'aly, A.I.; Al Rehaili, A.M.; Al Zarah, A.I.; Khan, M.A. Assessment of nitrate concentration in groundwater in Saudi Arabia. Environ. Monit. Assess. 2010, 161, 1-9. [CrossRef]

10. Mohebbi, M.R.; Saeedi, R.; Montazeri, A.; Azam Vaghefi, K.; Labbafi, S.; Oktaie, S.; Abtahi, M.; Mohagheghian, A. Assessment of water quality in groundwater resources of Iran using a modified drinking water quality index (DWQI). Ecol. Indic. 2013, 30, 28-34. [CrossRef]

11. Badr, E.S.A.; Al Naeem, A.A. Potable Water Quality Assessment in Al-Hassa, Eastern Region of Saudi Arabia. Fresenius Environ. Bull. 2016, 25, 4118-4129.

12. Perez-Gonzalez, A.; Urtiaga, A.M.; Ibanez, R.; Ortiz, I. State of the art and review on the treatment technologies of water reverse osmosis concentrates. Water Res. 2012, 46, 267-283. [CrossRef] [PubMed]

13. SASO. Bottled and Unbottled Drinking Water; Standard No. 409; SASO (Saudi Arabian Standards Organization): Riyadh, Saudi Arabia, 2009.

14. WHO. Guidelines for Drinking Water Quality, 4th ed.; World Health Organization: Geneva, Switzerland, 2011.

15. Massoud, M.A.; Al-Dakheel, Y.Y.; Hussein, A.H.; El-Mahmoudi, A.S. Spatial Decision Support System for Drinking Water Quality Monitoring and Evaluation in Al-Hassa. Int. J. Water Resour. Arid Environ. 2011, 1, 457-468.

16. Ma, J.Z.; Ding, Z.Y.; Wei, G.X.; Zhao, H.; Huang, T.M. Sources of water pollution and evolution of water quality in the Wuwei basin of Shiyang river, Northwest China. J. Environ. Manag. 2009, 90, 1168-1177. [CrossRef] [PubMed] 
17. Zaidi, F.K.; Mogren, S.; Mukhopadhyay, M.; Ibrahim, E. Evaluation of groundwater chemistry and its impact on drinking and irrigation water quality in the eastern part of the Central Arabian graben and trough system, Saudi Arabia. J. Afr. Earth Sci. 2016, 120, 208-219. [CrossRef]

18. Ikem, A.; Osibanjo, O.; Sridhar, M.K.C.; Sobande, A. Evaluation of groundwater quality characteristics near two waste sites in Ibadan and Lagos, Nigeria. Water Air Soil Pollut. 2002, 140, 307-333. [CrossRef]

19. Soltan, M.E. Evaluation of ground water quality in Dakhla Oasis (Egyptian Western Desert). Environ. Monit. Assess. 1999, 57, 157-168. [CrossRef]

20. Al-Naeem, A.A. Monitoring of Groundwater Salinity for Water Resources Management in Irrigated Areas of Al-Jouf Region, Saudi Arabia. Res. J. Environ. Sci. 2015, 9, 256-269. [CrossRef]

21. Al-Otaibi, E.L.; Zaki, M.S. Physico-chemical Quality of Drinking Water at Mushait, Aseer, South-Western, Saudi Arabia. Afr. J. Clin. Exp. Microbiol. 2009, 10, 117-127. [CrossRef]

22. Al-Zarah, A.I. Elemental Composition of Groundwater and Spring Waters in Al-Ahsa Oasis, Eastern Region Saudi Arabia. Trends Appl. Sci. Res. 2011, 6, 1-18. [CrossRef]

23. Karavoltsos, S.; Sakellari, A.; Mihopoulos, N.; Dassenakis, M.; Scoullos, M.J. Evaluation of the quality of drinking water in regions of Greece. Desalination 2008, 224, 317-329. [CrossRef]

24. Gupta, A.K.; Gupta, S.K.; Patil, R.S. A comparison of water quality indices for coastal water. J. Environ. Sci. Health Part A-Toxic/Hazard. Subst. Environ. Eng. 2003, 38, 2711-2725. [CrossRef]

25. Lateef, K.H. Evaluation of groundwater quality for drinking purpose for tikrit and samarra cities using water quality index. Eur. J. Sci. Res. 2011, 58, 472-481.

26. Rahaman, M.F.; Ali, M.S.; Arefin, R.; Mazumder, Q.H.; Majumder, R.K.; Jahan, C.S. Assessment of drinking water quality characteristics and quality index of Rajshahi city, Bangladesh. Environ. Dev. Sustain. 2020, 22, 3957-3971. [CrossRef]

27. Saeedi, M.; Abessi, O.; Sharifi, F.; Meraji, H. Development of groundwater quality index. Environ. Monit. Assess. 2010, 163, 327-335. [CrossRef] [PubMed]

28. Ahmed, J.; Wong, L.P.; Chua, Y.P.; Channa, N. Drinking Water Quality Mapping Using Water Quality Index and Geospatial Analysis in Primary Schools of Pakistan. Water 2020, 12, 3382. [CrossRef]

29. Stambuk-Giljanovic, N. Water quality evaluation by index in Dalmatia. Water Res. 1999, 33, 3423-3440. [CrossRef]

30. Almuhanna, E.A. Atmospheric aerosol characterization and element composition at Al-Ahsa Oasis of Saudi Arabia. Sci. J. King Faisal Univ. Basic Appl. Sci. 2017, 18, 35-47.

31. Al Omran, A.M.; El Maghraby, S.E.; Aly, A.A.; Al Wabel, M.I.; Al Asmari, Z.A.; Nadeem, M.E. Quality assessment of various bottled waters marketed in Saudi Arabia. Environ. Monit. Assess. 2013, 185, 6397-6406. [CrossRef]

32. APHA. Standard Methods for the Examination of Waters and Wastewaters, 20th ed.; American Public Health Association (APHA): Washington, DC, USA, 2005.

33. Adams, V.D. Water E Wastewater Examination Manual; Lewis Publishers: Chelsea, MI, USA, 1990.

34. Hanrahan, G.; Gardolinski, P.; Gledhill, M.; Worsfold, P. Environmental monitoring of nutrients. In Environmental Monitoring Handbook; Burden, F.R., Mckelvie, I.D., Forstner, U., Guenther, A., Eds.; McGraw-Hill: New York, NY, USA, 2002; pp. 8.1-8.16.

35. Simoes, F.d.S.; Moreira, A.B.; Bisinoti, M.C.; Gimenez, S.M.N.; Yabe, M.J.S. Water quality index as a simple indicator of aquaculture effects on aquatic bodies. Ecol. Indic. 2008, 8, 476-484. [CrossRef]

36. Yidana, S.M.; Yidana, A. Assessing water quality using water quality index and multivariate analysis. Environ. Earth Sci. 2010, 59, 1461-1473. [CrossRef]

37. Sanchez, E.; Colmenarejo, M.F.; Vicente, J.; Rubio, A.; Garcia, M.G.; Travieso, L.; Borja, R. Use of the water quality index and dissolved oxygen deficit as simple indicators of watersheds pollution. Ecol. Indic. 2007, 7, 315-328. [CrossRef]

38. Ramakrishnaiah, C.R.; Sadashivaiah, C.; Ranganna, G. Assessment of Water Quality Index for the Groundwater in Tumkur Taluk, Karnataka State, India. E-J. Chem. 2009, 6, 523-530. [CrossRef]

39. Sadiq, M.; Hussain, G. Drinking water quality in Saudi Arabia-An overview. Arab. J. Sci. Eng. 1997, 22, $153-164$.

40. Al-Ghanim, K.A.; Abd El-Salam, M.M.; Mahboob, S. Assessment of Water Quality for Some Roof Tanks in Alkharj Governorate, KSA. Pak. J. Zool. 2014, 46, 1003-1012.

41. Nouri, D.A.; Abdulkarim, B.A.; Arzoo, S.; Bakeet, Z.A.N. Quality Characteristics of Commonly Consumed Drinking Water in Riyadh and Effect of Domestic Treatments on Its Chemical Constituents. J. Food Nutr. Res. 2014, 2, 25-33.

42. Alabdulaaly, A.I. Nitrate concentrations in Riyadh, Saudi Arabia drinking water supplies. Environ. Monit. Assess. 1997, 47, 315-324. [CrossRef]

43. Piper, A.M. A graphic procedure in the geochemical interpretation of water-analyses. Trans. Am. Geophys. Union 1944, 25, 914-923. [CrossRef] 